\title{
Bacterial Isolates and their Antibiotic Susceptibility in Bile of Patients with Gallstone in Al-Hussein Teaching Hospital
}

\author{
Saad A. Atiyah ${ }^{(1)}$, Muhanad Abdulretha ${ }^{(2)}$, Abdul-kareem Salman Al-Yassari ${ }^{(3)}$ \& \\ Younus A. Kamel ${ }^{(4)}$ \\ ${ }^{(1)}$ Dept. Microbiologylcollege of medicinelUniversity of Thi-Qar \\ ${ }^{(2)}$ Dept. Surgerylcollege of medicinelUniversity of Thi-Qar \\ ${ }^{(3)}$ College of Vet. Med./University of AL-Qasim Green \\ (4) Thi-Qar Directorate of Health \\ Saad-abd@utq.edu.iq ${ }^{1}$ \\ $\underline{\text { Muhaned-abd@utq.edu.iq }}^{2}$
}

\begin{abstract}
:
The bacterial colonization in gallbladder represent important factor in initiation of gallstone and chronic cholecystitis. The aim of the study was to detect the facultative anaerobic bacterial isolates and determination of the most efficient antibiotics in treatment of gallbladder infections. Bile specimens were collected from 62 patients who have suffered from gallstone cultivated on bacteriological media, the diagnosis of isolates and antibiotic susceptibility test for the following antibiotics (CIP,NOR,AK,CN,CTX,CRO,CL,AMC,SXT,AZM and TET) was done by using standard bacteriological techniques. According to results $(14.51 \%)$ of the examined bile specimens were positive cultures with predominance of $E$. coli which represent $(54.55 \%)$ of isolates followed by Enterobacter spp. (18.18\%) with high significant differences $(\mathrm{P}<0.001)$, The flouroquinolones (CIP \& NOR) were most effective antibiotics followed by aminoglycosides $(\mathrm{AK}, \mathrm{CN})$ and $\mathrm{CTX}$ under $(\mathrm{P}<0.05)$. Furthermore, the isolates showed high and complete resistance to other antibiotics. In brief, colonization of bacteria may associated with the formation of gallstone where the E. coli is the most frequent bacterial isolates and the flouroquinolones (CIP \& NOR) appear to be highly effective against isolated bacteria and may play a role in treatment of infections.
\end{abstract}

Key wards: Gallstone, Bacterial Colonization, Flouroquinolones.

\section{Introduction}

this obstruction causes distention, bile stasis (absence of bile drift to and from the gall bladder), inflammation and

Cholecystitis is caused by obstruction of the biliary tract due to the existence of gallstones. Typically, 


\section{Email:utjmed@utq.edu.iq}

infection of the gall bladder $^{(1,2)}$.Probable risk factors for gallstone disease include rapid weight loss, obesity,high dietary intake of fat, multiple deliveries and congenital hemolytic anemia such as sickle cell disease $^{(3)}$. Bacteria play a vital role in the establishment of gallstones ${ }^{(1,2)}$. Bacterial isolates were found and associated with different types of gallstone such as pigment and cholesterol stone Different studies planned the association between bacterial colonization, the creation and pathogenesis of gallstone. Different types of bacteria were isolated from bile and gall-stone like (e.g., Escherichia coli, Pseudomonas aeruginosa, Entercoccus spp., Klebsiella pneumoniae, Citrobacter freundii, Salmonella spp., Helicobacter spp., Enterobacter spp.), particularly as living bacteria can be cultivated from cholesterol gallstones $^{(3,4,5,6)}$. Bacterial virulence factors support the institution of bacteria in bile such as multidrugresistance (MDR) efflux pump proteins produce resistance to bile salts, $\beta$ glucuronidase, phospholipases, bile acid hydrolases and slime materials assist the progress of gallstone ${ }^{(3,7)}$.The author's showed an important correlation between chronic bacterial colonization and the formation of gallstone such : approximately $90 \%$ of Sal. typhi chronic carrier have a gallstone $^{(8)}$.

The pathological role of bacteria in the formation of gallstones was planned long ago. Bacteria are frequently presents in high concentrations in brown pigment and less so in
Web Site: https://imed.utq.edu.iq

cholesterol gallstones. Although it is intriguing to hypothesize that cholesterol stone formation is nonbacterial in nature and fundamentally different from the pathogenesis of "infectious" brown pigment gallstones, it is more likely that significant overlay exists between the two processes. This is in custody with the fact that most gallstones are mixed in nature ${ }^{(7,9)}$.

A suitable treatment by antibiotics is essential in the controlling of biliary tract infection and antibiotics are usually used pre- or peri-operatively and often inhibits the bacterial growth. But, antibiotic resistant isolates are spread worldwide including these from gallbladder which represents a real problem in treatment of the patients especially those with gall stone leading to initiation of chronic infections ${ }^{(10,11)}$.

This study was designed to determines the facultative anaerobic bacterial isolates in bile and detects the types of antibiotics that aid in treatment of gallbladder infections.

\section{Materials and Methods}

\section{Specimen}

The study was performed in AlHussein teaching hospital in a period from September/2014 to April/2015. A total of 62 patients suffering from gallstone were included in this study and the bile specimens were collected by a sterile needle.

\section{Bacterial isolation and identification} The bile specimens were cultured on blood and MacConkey's agar plates (Himedia-India) then they incubated aerobically at $37{ }^{\circ} \mathrm{C}$ for 24 hours, the 


\section{Email:utjmed@utq.edu.iq}

bacterial colonies were identified by using standard bacteriological techniques $^{(12,13)}$.

\section{Antibiotics susceptibility}

This test was performed by disk diffusion technique (the Kirby-Bauer susceptibility test) by using following antibiotics ciprofloxacin (CIP), norfloxacin (NOR), amikacin (AK),
Web Site: https://imed.utq.edu.iq

gentamicin $(\mathrm{CN})$, cefotaxime (CTX), cefitriaxone (CRO), cephalexin (CL), co-amoxyclav (AMC), co-trimoxazole (SXT), azithromycin (AZM) and tetracycline (TET) discs provided by (Bioanalyze-Turkey) ${ }^{(14)}$

\section{Statistics}

The statistical analysis was performed by using SPSS program (version 19).

\section{Results}

The frequency of positive bile culture cases in patients with gallstone was 9 $(14.51 \%)$ of total examined bile specimens where 2 cases associated with mixed bacterial infections. While $53(85.49 \%)$ was negative culture as shown in table (1).

Table (1): Bacterial colonization cases in bile of patients with gallstone.

\begin{tabular}{|c|c|c|}
\hline Cases & No. & Percent (\%) \\
\hline Positive & 9 & 14.51 \\
\hline Negative & 53 & 85.49 \\
\hline Total & 62 & 100 \\
\hline
\end{tabular}

Table (2) illustrate the frequency of bacterial isolates among positive culture patients. Where, Enterobacter spp. isolated from 2 (18.18\%) cases , coagulase negative staphylococci (CoNs) in1 $(9.09 \%)$ case. While, E. coli was predominant in 6 (54.55\%) of cases with high significant differences $(\mathrm{P}<0.001), S$. typhi and Citrobacter spp. were isolated in mixing state with E. coli in frequency (9.09\%) for each isolate.

Table (2): The frequency of microbial isolates among positive bile cultures.

\begin{tabular}{|c|c|c|}
\hline Types & Frequency & Percent \\
\hline E. coli & 6 & 54.55 \\
\hline Enterobacter spp. & 2 & 18.18 \\
\hline CoNs & 1 & 9.09 \\
\hline Salmonella typhi* & 1 & 9.09 \\
\hline Citrobacter spp. & 1 & 9.09 \\
\hline Total & 11 & 100 \\
\hline
\end{tabular}


*A two cases shown mixed growth of ( E. coli \& S. typhi ) and ( E.coli \& Citrobacter spp.), respectively.

Antibiotic susceptibility of the bacterial isolates shown in table (3). Isolates were high susceptible to CIP and NOR (72.72\%) for each one, While, the isolates shown moderate susceptibility to AK, CN, CTX $(63.63,45.45$ and $45.45 \%)$ respectively and cephalexin revealed low susceptibility value against isolated bacteria (27.27\%) under $(\mathrm{P}<0.05)$. All isolates were resistant to AMC, SXT, TET, AZM and CRO.

Table (3): Antibiotic susceptibility of bacteria isolated from bile.

\begin{tabular}{|c|c|c|c|c|c|c|c|c|}
\hline \multirow{2}{*}{ Antibiotics } & \multicolumn{2}{|c|}{ Susceptible } & \multicolumn{2}{c|}{$\begin{array}{c}\text { Intermediate } \\
\text { susceptibility }\end{array}$} & \multicolumn{2}{c|}{ Resistant } & \multicolumn{2}{c|}{ Total } \\
\cline { 2 - 9 } & No. & $\%$ & No. & $\%$ & No. & $\%$ & No. & $\%$ \\
\hline CIP & 8 & 72.72 & 1 & 9.09 & 2 & 18.18 & 11 & 100 \\
\hline NOR & 8 & 72.72 & 0 & 0 & 3 & 27.27 & & \\
\hline AK & 7 & 63.63 & 3 & 27.27 & 1 & 9.09 & & \\
\hline CN & 5 & 45.45 & 1 & 9.09 & 5 & 45.45 & \\
\hline CTX & 5 & 45.45 & 0 & 0 & 6 & 54.54 & \\
\hline CL & 3 & 27.27 & 1 & 9.09 & 7 & 63.63 & \\
\hline AMC & 0 & 0.0 & 0 & 0.0 & 11 & 100 & \\
\hline SXT & 0 & 0.0 & 0 & 0.0 & 11 & 100 & \\
\hline TET & 0 & 0.0 & 0 & 0.0 & 11 & 100 & \\
\\
\hline AZM & 0 & 0.0 & 0 & 0.0 & 11 & 100 & \\
\hline CRO & 0 & 0.0 & 0 & 0.0 & 11 & 100 & & \\
\hline
\end{tabular}

\section{Discussion}

The incidence of bile and gallstone infection varies considerably from area to area in the world and also among different countries in a given area. Enteric organisms have often been suspected of causing cholelithiasis and the intestinal flora have frequently been recovered following interventions on the biliary tree,the present study shows that E.coli to be the commonest organism isolates $(54.55 \%)$ followed by Enterobacter spp. in $(18.18 \%)$ cases, whereas Salmonella typhi. was observed in only $9.09 \%$ of cases. The result was comparable to several studies which indicate that the enteric bacteria especially E. coli were the

most prevalent isolates from bile specimens ${ }^{(1,6,15,16)}$.

Development of chronic bacterial colonization are associated with abnormal conditions of gallbladder involving gallstone. The enteric bacteria able to colonize the gallbladder due to their ability to resist 


\section{Email:utjmed@utq.edu.iq}

bile and other inhibitors in this site, these bacteria have many virulence factors such as adhesins including (pili and capsule) that promote bacterial attachment and subsequent colonization on biological surfaces including mucus membrane.All these factors along with the great capacity of enteric bacteria to produce biofilm help in colonization of enteric bacteria and initiation of chronic infections in gallbladder. Biofilm protects bacteria from undesired conditions such as immune cells and antibiotics through its ability to decrease penetration of drugs and prevent cells from reaching to microbes that help in colonization of enterobacteria and initiate acute and chronic infections of gallbladder, where the biofilm cannot be eradicated by antibiotics until its removed physically $^{(17,18,19)}$.

The researchers showed the capacity of enterics like: E. coli and salmonella to produce a strong biofilm in cholesterol coated surfaces, the colonization of microflora are affected by human physiology and diets ${ }^{(2,3)}$, these factors along with bacterial virulence factors such as $\beta$ glucouronidase and phospholipases that produced by bacteria e.g. E. coli etc. participate in the formation of different types of gall stone ${ }^{(7,20)}$.

Antibiotic sensitivity patterns of isolated bacteria were similar irrespective of the types of stone, the isolates under study showed mild resistance to (CIP,NOR,\& AK) and high resistance to others where all isolates have been tested were multidrug resistant which reflects the difficulty in treatment of these infections, this phenomena may be occur due to ability of enteric bacteria to release biofilm that prevent or decrease penetration of antibiotics to deep layers of biofilm and enhance the development of resistance where biofilm facilitates the communication of different types of bacteria. Also, the capacity of enteric bacteria to initiate different types of mechanisms of resistance such as: production of antibiotic destruction and modifying enzymes may participate in antibiotic resistance of bacterial isolates as mentioned in previous studies ${ }^{(1,21,22)}$.

\section{Conclusion}

Bacterial colonization may assist in the formation of gallstone where the $E$. coli is the most frequent bacteria in bile from patients with gallstone and the flouroquinolones (CIP \& NOR) appear to be highly effective against isolated bacteria and may play a role in treatment of infections.

\section{References}

1. Abeysuriya, V.,Deen, K.I.,Wijesuriya, T. and Salgado, S.S. (2008). Microbiology of gallbladder bile in uncomplicated symptomatic cholelithiasis. Hepatobiliary Pancreat. Dis. Int. 7(6): 633-637.

2. Swidsinski, A., Ludwig, W., Pahlig, H. and Priem, F. ( 1995). Molecular genetic evidence of bacterial 


\section{Email:utjmed@utq.edu.iq}

colonization of cholesterol gallstones. Gastroenterology. ;108(3):860-4.

3. Cotran, R., Kumar, V., Collins, T., Robbins, S. and Schmitt, B. (1999).Robbins'Pathologic Basis of Disease. 6th ed. Boston: WB Saunders, 1999:454-478.

3. Maki, T. (1966). Pathogenesis of calcium bilirubinate gallstone: role of E. coli, beta-glucuronidase. and coagulation by inorganic ions, polyelectrolytes and agitation.. Ann. Surg. 164(1):90-100.

4. Portincasa, P., Moschetta, A. and Palasciano, G. (2006). Cholesterol gallstone disease.Lancet. 368(9531):230-239.

5. Alexander, S., Wolfgang, L., Hartmut, P. and Friedrich, P. (1995). Molecular genetic evidence of bacterial colonization of cholesterol gallstones.Gastroenterology.

108(3):860-864.

6. Hazrah, P., Oahn, K.T., Tewari, M., Pandey, A.K., Kumar, K., Mohapatra, T.M. and Shukla, H.S. (2004). The frequency of live bacteria in gallstones.HPB (Oxford). 6(1):28-32.

7. Stewart, L., Grifiss, J.M., Jarvis, G.A. andWay, L.W. (2006). Biliary bacterial factors determine the path of gallstone formation. Am. J. Surg. 192(5):598-603.

8. Gonzalez-Escobedo, G., Marshall, J.M. and Gunn. J.S.(2011). Chronic and acute infection of the gall bladder by Salmonella Typhi: understanding the carrier state. Nat Rev Microbiol. 9(1): 9-14.

9. Swidsinski, A. and Lee, S.P. (2001). The role of bacteria in gallstone pathogenesis. Front Biosci. 6: 93-103.
10. Cheng, H.Y., Yang, H.Y. and Chou, C.C.. Influence of acid adaptation on the tolerance of Escherichia coli $\mathrm{O} 157: \mathrm{H} 7$ to some subsequent stresses. J Food Prot 2002; 65: 260-265.

11. Mendes, C., Hsiung, A., Kiffer, C., Oplustil, C., Sinto, S., Mimica, I. and Zoccoli, C. (2000). Evaluation of the in vitro activity of 9 antimicrobials against bacterial strains isolated from patients in intensive care units in Brazil: MYSTIC Antimicrobial Surveillance Program. Braz. J. Infect. Dis. 4:236-244.

12. Collee, J.G., Fraser, A. G., Marmion, B. P. and Simmon, A. (1996). Makic and McCartncy medical microbiology. $14^{\text {th }}$. the Churchill living stone.

13. Baron, E. J. ; Peterson, L. P. and Fengold, S. M. (1994) . Diagnostic Microbiology . 9 thed . Mosby

14. Clinical and Laboratory Standards Institute - (2014). Performance Standards for Antimicrobial Susceptibility Testing; Twenty-Fourth Informational Supplement.

15. Leung, J.W., Sung, J.Y. and Costerton, J.W. (1989). Bacteriological and electron microscopy examination of brown pigment stones. J. Clin. Microbiol. 27:915-921.

16. Capoor, M.R. (2008). Microflora of bile aspirates in patients with acute cholecystitis with or without cholelithiasis: a tropical experience.

Braz. J Infect. Dis. 12:222-225 


\section{Email:utjmed@utq.edu.iq}

17. Crawford, R., Rosales-Reyes, R., Ramírez-Aguilar, M.L., Chapa-Azuela, O., Alpuche-Aranda, S. and Gunn, J.S. (2010). Gallstones play a significant role in Salmonella spp. gallbladder colonization and carriage. Nat. Acad. Sci. USA. 107 (9).

18 . Costerton, J. W.; Stewart, P. S. and Greenberg, E. P. (1999) . Bacterial biofilm : A common cause of persistent infections . Science . 248: 1318-1322.

19. Stewart, P. S. (2002) . Mechanism of antibiotic resistance in bacterial biofilms . Int. J. Med. Microbiol. 292: 107-113.

20. Ledeboer, N.A. and Jones, B.D. (2005).Exopolysaccharide sugars contribute to biofilm formation by Salmonella enterica serovar Typhimurium on HEp-2 cells and
Web Site: https://imed.utq.edu.iq

chicken intestinal epithelium. J. Bacteriol. 187:3214-3226.

21. Fatemi, S., Doosti, A., Tavakoli,

H., Moayednia, R., Ghasemi-Dehkordi, P., Kelidari, B., Mahmudieh, M. and Moayednia, M. (2015). Antibiotic susceptibility patterns of isolated bacteria from bile fluids of patients with gallstone disease in Isfahan (Iran). Arch. Biol. Sci. Belgrade. 67(2), 611617

22. Ballal, M., Jyothi, K. N., Antony, B., Arun, C., Prabhu, T. and Shivananda, P.G. (2001). Bacteriological spectrum of cholecystitis and its antibiogram. Indian J. Med. Microbiol. 19(4),212214. 


\section{تردد العزلات الجرثومية في الصفراء من المرضى الأين يعانون من حصوات المرارة وحساسيتها للمضادات الحئ الحيوية النين}

سعد عبد العزيز عطية

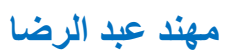

يونس عطية كامل

عبد الكريم سلمان اليساري

الخلاصة : الخطان

استيطان الجراثيم في المرارة يمثل عاملا مهما في بدء تكوين حصى المرارة والإصسابات

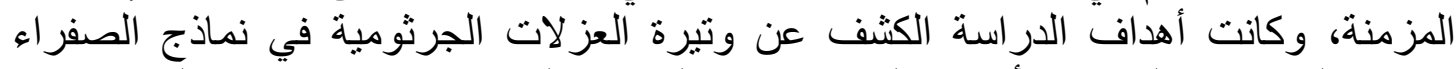

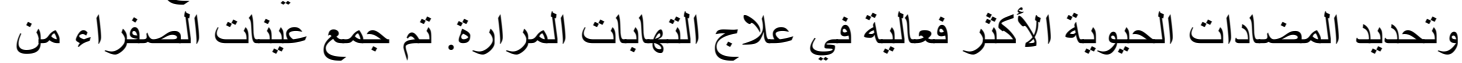

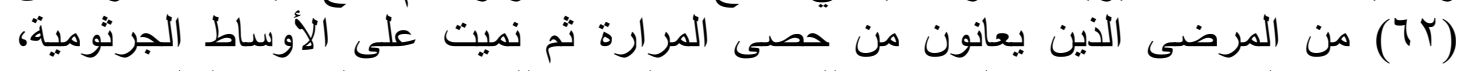
وتشخيص العزلات واختبار الحساسية للمضادات الحيوية للمضادات الحيوية التالية (CIP)، (AZM ،SXT ،AMC ،CL ،CRO ،CTX ،CN ،AK ،NOR

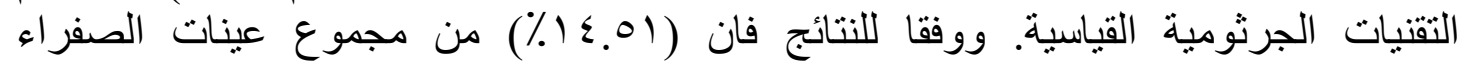

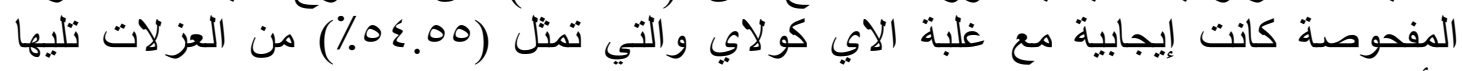

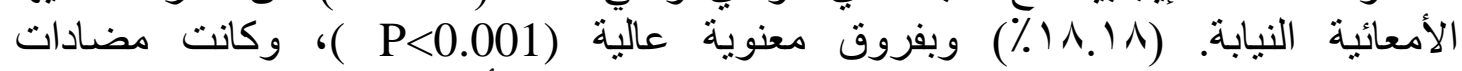

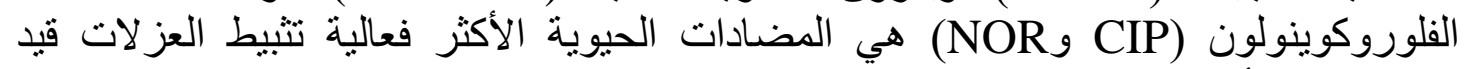

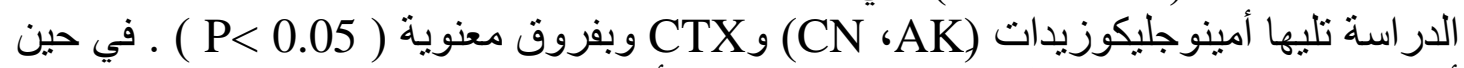

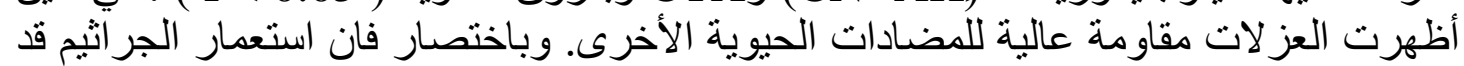

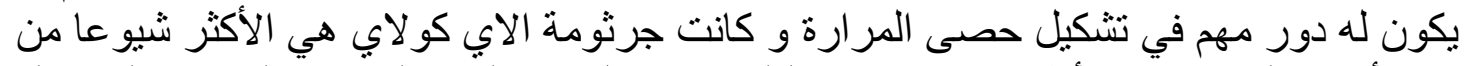

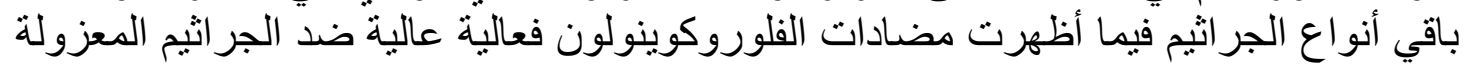
وقد تلعب دور أفي علاج التهابات. 